\title{
Dávid HOJNYÁK*
}

\section{Current tendencies of the development of the right to a healthy environment in Hungary in the light of the practice of the Constitutional Court in recent years ${ }^{* *}$}

\author{
Abstract
}

In recent years, there have been several Constitutional Court decisions dealing with the right to a bealthy environment and its interpretation. In these decisions, the Constitutional Court has further developed and partially renewed the content of the right to a bealthy environment and its interpretation, which was necessary and justified following the adoption of the Fundamental Law of Hungary, and especially following its fourth amendment. Accordingly, the present study reviews the recent changes in the content and interpretation of the right to a bealthy environment and the new tendencies that can be observed in this context by analysing the practice of the Constitutional Court of Hungary.

Keywords: right to a healthy environment; environmental protection; Fundamental Law of Hungary; Constitutional Court of Hungary.

\section{The fourth amendment to the Fundamental Law of Hungary and its impact on the dogmatics of the right to a healthy environment}

Although it is not the aim of the present work to analyze the provisions of the Fundamental Law of Hungary that are relevant from an environmental law perspective, ${ }^{1}$ we consider it important to note that compared to the regulations of the previous Constitution, in the Fundamental Law, which came into force on 1 January 2012, the issue of environmental values and environmental protection appears more

Dávid Hojnyák: Current tendencies of the development of the right to a healthy environment in Hungary in the light of the practice of the Constitutional Court in recent years. Journal of Agricultural and Environmental Law ISSN 1788-6171, 2021 Vol. XVI No. 31 pp. 39-54, https://doi.org/10.21029/JAEL.2021.31.39

* PhD student, Department of Agricultural and Labour Law, Faculty of Law, University of Miskolc; researcher, Ferenc Mádl Institute of Comparative Law, e-mail: joghojnyak@unimiskolc.hu.

** This study has been written as part of the Ministry of Justice programme aiming to raise the standard of law education.

${ }^{1}$ For a detailed analysis of the environmentally relevant provisions of the Fundamental Law, see in particular: Bándi 2013, 67-92.; Horváth 2013, 222-234. For the interpretation of the provision of the Fundamental Law concerning GMO-free agriculture, see in particular: T. Kovács 2015, 308-314.; Fodor 2018, 48-50. and Szilágyi 2021a, 455-464. Regarding the concept of the right to food included in the Fundamental Law, see in particular: T. Kovács 2017, 76-78., 126-127., 144-145. and Szilágyi, Hojnyák \& Jakab 2021, 72-86. For a detailed analysis of the water provisions of the Fundamental Law, see in particular: Fodor 2013, 329-345. and Raisz 2012, 156-157. 
widely and with greater emphasis. We see that from the National Avowal, which functions as a preamble, to the chapter entitled 'Foundation' that contains general provisions and principles, to the chapter 'Freedom and Responsibility', which deals with constitutional fundamental rights, and to 'The State', the Fundamental Law contains environmental law provisions. Before reviewing the case law of the Constitutional Court it can be stated, based merely on the comparison of the previous and the current constitutional regulation, that environmental values, environmental protection, sustainable development, and future generations are given more weight in the Fundamental Law. ${ }^{2}$ In our view, all this is related, among other things, to the fact that, compared to the previous Constitution, which is considered to be value-neutral, the current Fundamental Law has a value-bearing character, one of the manifestations of which is the protection of the environment in the document itself. In the light of all this, it is not surprising to find that among the national constitutions of the European Union, the Hungarian constitution regulates the most comprehensively relevant areas from the point of view of environmental policy. ${ }^{3}$ According to László Fodor, a constitution recognizing environmental values can formally contribute to the development of an environmentally friendly legal order in such a way that it provides a basis for reference and creates an obligation to define environmental protection requirements. ${ }^{4}$ In our view, the regulation of the Fundamental Law meets these criteria.

The fourth amendment to the Fundamental Law is relevant to the present work because as a result of the amendment the decisions of the Constitution Court before its entry into force were rendered lapse, i.e. the Constitutional Court was not bound by its decisions and case law that is based on the previous Constitution. ${ }^{5}$ According to the explanatory memorandum to the proposal for the fourth amendment of the Fundamental Law, the purpose and legal policy reason of the amendment was to interpret the provisions of the Fundamental Law in the context of the Fundamental Law itself, independently of the system of the previous Constitution. However, the amendment and its explanatory memorandum also stated that this act does not affect the legal effects of the decisions of the Constitutional Court in this area, i.e. issued based on the regulations of the previous Constitution, nor does it forbid the Constitutional Court to refer to previous decisions. It must be noted that the latter cannot be ruled out simply because the Fundamental Law itself states that the provisions of the Fundamental Law must be interpreted in accordance with the achievements of the historical constitution, ${ }^{6}$ and the former Constitution and the case

\footnotetext{
2 As Attila Antal puts it '[...] the adopted Fundamental Law has a strong environmental policy profile, an environmental philosophy, if you will.' Antal 2011, 47.

${ }^{3}$ Kiss 2017, 257. László Fodor takes the same position. See Fodor 2013, 337.

${ }^{4}$ Fodor 2006a, 65.

${ }^{5}$ Fundamental Law of Hungary, Final and mixed provisions, point 5. Ordained by Article 19 Paragraph (2) of the fourth amendment to the Fundamental Law.

${ }_{6}$ Paragraph (3) Article R) of the Fundamental Law of Hungary. See more in this regard: Trócsányi 2014, 59-62. Paragraph 17 of the National Avowal is also relevant in this regard, which, in our view, should be read in conjunction with Paragraph (3) Article R). Paragraph 17 of the National Avowal states: "We respect the achievements of our historical constitution and the Holy Crown, which embodies the constitutional national continuity of Hungary and the unity of the nation".
} 
law of the Constitutional Court developed on the basis thereof, falls within this scope. ${ }^{7}$ Due to such a change in the constitutional regulation, it was left to the Constitutional Court to clarify this issue. With regards to the right to a healthy environment, the interpretation of this provision was particularly important, as the case law of the Constitutional Court of more than two decades prior to the enactment of the Fundamental Law was of paramount importance in shaping and developing the dogmatics of this right.

Shortly after the entry into force of the fourth amendment to the Fundamental Law on 1 April 2013, the Constitutional Court also ruled on this issue ${ }^{8}$ but did so in a general manner for the time being, as the issues of interpretation of the right to a healthy environment were not directly addressed at that time. From the abovementioned decision of the Constitutional Court, the following findings are of huge importance to our topic and the problems raised. As stated in the reasoning of the decision, the Constitutional Court may refer to or cite the arguments, legal principles, and constitutional contexts developed in its previous decisions if there is no obstacle to the applicability of such findings based on substantive conformity of the relevant section of the Fundamental Law with the Constitution, taking into account the rules of interpretation of the Fundamental Law and that there is no obstacle based on the specific case. 9 At the same time, it was also established that the applicability of these arguments, legal principles, and constitutional contexts must always be examined by the Constitutional Court on a case-by-case basis, looking at the context of the specific problem. ${ }^{10}$ The Constitutional Court has thus established a link - or legal continuity if you will - between the provisions of the Fundamental Law and the applicability of its decisions based on the previous Constitution and the principle findings expressed therein. The connection between the previous and the current constitutional regulation regarding the right to a healthy environment was finally established by the Constitutional Court's Decision 16/2015 (VI.5.).

\section{The findings of Decision $16 / 2015$ on the dogmatics of the right to a healthy environment}

Decision 16/2015 is of outstanding importance for the subject of the present study in two aspects. Firstly, in this decision, the Constitutional Court reaffirmed its practice concerning the dogmatics of the right to a healthy environment established before the enactment of the Fundamental Law, and on the other hand, it interpreted the environmentally relevant provisions of the Fundamental Law. ${ }^{11}$ In the following, Decision 16/2015 will be analyzed along with these two aspects.

\footnotetext{
${ }^{7}$ Cf.: Varga Zs. 2016, 87-88.

8 The Constitutional Court made principle statements in Decision 13/2013 (VI.17.) in connection with the problem raised.

9 The reasoning of Decision 13/2013 [32].

10 The reasoning of Decision 13/2013 [33]-[34].

${ }^{11}$ It should be noted at this point that prior to Decision 16/2015, regardless of the fourth amendment to the Constitution, the Constitutional Court would have had the opportunity to
} 


\subsection{Strengthening the dogmatics of the right to a healthy environment}

In Part $\mathrm{V}$ of the explanatory memorandum of the decision, the Constitutional Court reviewed the dogmatics of the right to a healthy environment through the development of the Hungarian Constitution and the relevant case law of the Constitutional Court. Prior to this, however, the Constitutional Court examined the development of the right to a healthy environment and environmental protection in its international context, recording the key findings of the Stockholm Declaration (1972), the Rio Declaration (1992), the Johannesburg Declaration (2002) and the Rio 20+ Declaration (2012) and also briefly touched upon the work of the Club of Rome and the Brundtland Commission. ${ }^{12}$ It is important to emphasize all this at this point because the Constitutional Court considers the dogmatics developed by it to be a pioneer in an international context as well. ${ }^{13}$

Following this background, the Constitutional Court reviewed its own previous case law relevant to the dogmatics of the right to a healthy environment. ${ }^{14}$ Of the relevant case law of more than two decades, the Constitutional Court specifically highlights Decision 28/1994 (V.20.), which is aptly called the 'basic environmental decision' of the Constitutional Court, as in addition to the two environmentally relevant provisions of the previous Constitution, the principles and requirements it contains can be considered as the constitutional basis of the right to a healthy environment, which was then further developed and clarified by the Constitutional Court in several further decisions. ${ }^{15}$ Next, let us briefly review the most important elements of the dogmatics of the right to a healthy environment based on the interpretation of the Constitutional Court:

(a) The right to a healthy environment is a fundamental right which, however, is special among fundamental rights in a way that it has no subjective side, but which, because of its fundamental rights nature, is stronger than the objectives and duties of the state enshrined in the Constitution. This third-generation right with differentia specifica is, therefore "primarily an independent and inherent institutional protection, i.e. a specific fundamental right of which the objective, institutional protection side is predominant and decisive"

interpret the right to a healthy environment, now in view of the new constitutional regulations. The interpretation would have been based on Decision 44/2012 (XII. 20.) and the case on which it is based.

12 The reasoning of Decision 16/2015 [69]-[76].

13 The reasoning of Decision 16/2015 [79].

${ }^{14}$ The reasoning of Decision 16/2015 [80]-[86].

15 It should be noted that, although Decision 16/2015 bases the dogmatics of the right to a healthy environment primarily on the provisions of Decision 28/1994, it also refers to a number of other decisions which have also made a significant contribution to the design, development and clarification of the dogmatics. Thus, the Constitutional Court referred to the following decisions when defining the content elements of the right to the environment: Decision 64/1993 (XII.22.); Decision 27/1995 (V.15.); Decision 14/1998 (V.8.); Decision 48/1998 (XI.23.). 
and thus the right to a healthy environment "raises the guarantees of the state's fulfillment of its environmental obligations to the level of fundamental rights." 16

(b) With regard to the nature of the right to a healthy environment, the Constitutional Court also found that it is, in fact, part of the objective institutional protection of the right to life, and the Constitution thus "declares the state's obligation to maintain the natural foundations of human life as a separate constitutional right."17

(c) The state can ensure the right to a healthy environment primarily by providing legal and organizational guarantees. In this context, the Constitutional Court ruled that the extent of the institutional protection of the right to a healthy environment cannot be determined arbitrarily by the state, i.e. "the state does not enjoy the freedom to allow the state of the environment to deteriorate or to allow the risk of deterioration." From this requirement, among several others, one of the most important elements of the dogmatics of the right to a healthy environment, the so-called "non-derogation principle" (the prohibition of regression) follows. ${ }^{18}$ The purpose of this prohibition is to ensure that "the level of protection already achieved does not decrease", i.e. the state may not reduce the level of protection of nature and the environment already provided by legislation. ${ }^{19}$

(d) The reduction of the level of protection set out above - i.e. the restriction of the right to a healthy environment - is considered allowable by the Constitutional Court in one instance, namely when it is absolutely necessary for the enforcement of another fundamental right or constitutional value. ${ }^{20}$ Restriction of the right to a healthy environment is therefore only possible in accordance with the requirement of proportionality and necessity, by carrying out a fundamental rights test - however, all this has not yet happened. As it can be seen, the fundamental nature of the right to a healthy environment can also be seen in this respect.

(e) In addition to the non-derogation principle, the Constitutional Court also named several other environmental principles in its decision, such as the principle of prevention, ${ }^{21}$ the principle of proportionality ${ }^{22}$, or the principle of integration. ${ }^{23}$

(f) Another important finding of the Constitutional Court was stating that one of the means of enforcing the right to a healthy environment is that "the level of protection of the built environment provided by law cannot be reduced by legally non-binding official decisions", which means that the Constitutional Court extended the right to a healthy environment to the protection of the built environment, which also includes the protection of the urban environment and spatial planning. ${ }^{24}$

\footnotetext{
16 The reasoning of Decision 16/2015 [80].

17 The reasoning of Decision 16/2015 [85].

${ }^{18}$ For more about the non-regression see: Bándi 2017, 159-181.; Fodor 2006b, 109-131.

${ }^{19}$ The reasoning of Decision 16/2015 [81].

${ }^{20}$ The reasoning of Decision 16/2015 [80].

${ }^{21}$ The reasoning of Decision 16/2015 [81] and [109].

22 The reasoning of Decision 16/2015 [80] and [109].

${ }^{23}$ The reasoning of Decision 16/2015 [83].

${ }^{24}$ The reasoning of Decision 16/2015 [83].
} 
In addition to defining the main substantive elements of the constitutional fundamental right to a healthy environment, the Constitutional Court also stated that "the text of the Fundamental Law regarding the right to a bealthy environment is the same as the text of the Constitution, therefore the findings made in previous decisions of the Constitutional Court can also be considered relevant in the interpretation of the right to a healthy environment." 25 In Decision 16/2015, after reviewing its own previous case law, the Constitutional Court confirmed the main elements of the dogmatics of the right to a healthy environment, at the same time establishing the link between the previous and current constitutional regulations, i.e. the previous case law of the Constitutional Court regarding the right to the environment can be maintained and will be applicable in the future.

\subsection{Interpretation of the environmental provisions of the Fundamental Law}

Following the above, the Constitutional Court reviewed the environmental and nature protection provisions of the Fundamental Law. In doing so, the Constitutional Court stated that "the Fundamental Law not only preserved the level of protection of the fundamental right to a healthy environment, but also contains significantly more extensive provisions in this area than the Constitution. The Fundamental Law thus further developed the environmental values and approach of the Constitution and the Constitutional Court." Although the Constitutional Court itself states in the decision that "it is the task of the Constitutional Court to interpret and explain the content of the provisions of the Fundamental Law in today's circumstances", unfortunately, this was done only in an extremely narrow circle. ${ }^{26}$

In its decision, the Constitutional Court primarily interpreted Article P), in connection with which it found that Paragraph (1) Article P) raised the requirement to protect, maintain and preserve the environment and nature for future generations to a constitutional level. Paragraph (1) Article P) thus expressly regulates the state's obligation, and, on the other hand, defines what environmental protection actually means as the state's and citizens' obligation. In addition, the Constitutional Court considers the extension of the scope of obligations with regard to the protection of the environment to be a significant step forward compared to the regulation of the previous Constitution. While the Constitution focused exclusively on state obligations, the Fundamental Law extends environmental obligations to everyone, that is, to all citizens. ${ }^{27}$ The Constitutional Court also referred to the close relationship between Article P) and Article XXI stating that Paragraph (1) Article P) sets out an objective for the state, the achievement and implementation of which is ensured by the fundamental right derived from Paragraph (1) Article XXI. These two articles have been linked by the Constitutional Court to the prohibition of regression and, as we shall see later, to the precautionary principle, when it stated that "the fulfillment of the state objective and the

\footnotetext{
25 The reasoning of Decision 16/2015 [90]; It should be noted that the Constitutional Court has already established the above in Decision 3068/2013 (III.14.), however, the decision was issued before the fourth amendment to the Fundamental Law, and the dogmatics of the right to a healthy environment was not addressed in such detail by the Constitutional Court.

${ }^{26}$ The reasoning of Decision 16/2015 [91].

27 The reasoning of Decision 16/2015 [92].
} 
enforcement of the fundamental right to a healthy environment is ensured by the maintenance of the already achieved level of protection of the healthy environment' ${ }^{28}$

However, the Constitutional Court has stopped at this point and did not proceed with the interpretation of the provisions of the Fundamental Law. At the same time, it is important to refer to the concurring reasoning of Constitutional Judge Imre Juhász, in which he added an addition to the part of the decision interpreting Article P). Constitutional Judge Juhász also made three critical remarks regarding the reasons for the adopted decision. On the one hand, he expressed doubts as to whether the dogmatics of the right to a healthy environment, laid down almost 25 years ago, ${ }^{29}$ could be applied to the new provisions of the Fundamental Law. ${ }^{30}$ On the other hand, he pointed out that the Constitutional Court did not give sufficient weight to the conceptual change, which, in his view, had taken place in the constitutional regulation of environmental protection, the right to health, and the right to a healthy environment with the Fundamental Law's entry into force. ${ }^{31}$ Thirdly, in the concurring reasoning, he explains that the Constitutional Court did not use the possibility of interpretation in relation to the new provisions of the Fundamental Law, i.e. those that were not present in the previous Constitution. Constitutional Judge Juhász sees this as a missed opportunity, which would have been suitable for modernizing the dogmatics of the right to a healthy environment, stating that "in this respect, the decision remains indebted to the consistent solution of the task it has undertaken, i.e. the interpretation and explanation of the provisions of the Fundamental Law in today's circumstances". At the same time, he emphasizes that "the reasons for the decision, therefore, left the question partly unanswered of whether, and if so in what direction, had progress been made in the last 20 years in the field of constitutional environmental protection since the adoption of the deservedly important and rightly cited decision." 32 In any case, the statement of the concurring reasoning pointed out that there were still several questions to be answered regarding the provisions of the Fundamental Law on environmental law and the dogmatics of the right to a healthy environment.

\section{New directions and tendencies in the practice of the Constitutional Court of Hungary}

Six years have passed between the adoption of Decision 16/2015 and the finishing of the manuscript of the present work. In the light of the above, the question arises as to whether there has been a substantial change in the interpretation of the right to a healthy environment. In the following, without wishing to be exhaustive,

\footnotetext{
28 The reasoning of Decision 16/2015 [109].

${ }^{29}$ In connection with this, it should be noted that several Hungarian environmental lawyers have previously pointed out that the dogmatics of the right to a healthy environment is outdated, which - among several other circumstances - can be justified by the lack of legal development activities of the Constitutional Court. See: Fodor 2006c, 53-99.; Majtényi 2010, 21.; Fodor 2011, 4.; Bándi 2013, 91.

30 The reasoning of Decision 16/2015 [143].

31 The reasoning of Decision 16/2015 [144]-[145].

32 The reasoning of Decision 16/2015 [153].
} 
it is reviewed what new directions can be observed concerning the dogmatics of the right to a healthy environment in the light of the Constitutional Court's legal interpretation and legal development activities.

\subsection{The emergence of the precautionary principle as a constitutional principle in the case law of the Constitutional Court}

The precautionary principle has appeared in the recent practice of the Constitutional Court. ${ }^{33}$ From the legal practice's point of view, Decision 13/2018 (IX.4.) is of the greatest significance, as in this decision the Constitutional Court has so far dealt with the precautionary principle, more precisely with its interpretation, in the greatest detail. However, it is important to note that the precautionary principle appeared in the case law of the Constitutional Court before and after this 2018 decision. Accordingly, the following is a brief overview of the Constitutional Court's case law on the precautionary principle. ${ }^{34}$

The legal development implemented in Decision 13/2018 was preceded or substantiated if you will - by three decisions of the Constitutional Court. In the case law of the Constitutional Court, the precautionary principle first appeared in Decision 3223/2017 (IX.25.), namely as a principle of environmental legislation. In that regard, the decision states that "the main reason for the probibition of regression (non-derogation), as a regulatory line is that failure to protect nature and the environment can trigger an irreversible processes, so it is only possible to create regulations on environmental protection if we take into account the principles of precaution and prevention." 35 According to the decision, the legislator must therefore also take the precautionary principle into account when creating new legislation. ${ }^{36}$

The next decision to be examined, Decision $27 / 2017$ (X.25.) goes beyond all this in a way stating that this principle is one of the generally accepted principles of environmental law, however, it does not address its substantive issues. ${ }^{37}$ However, Decision 28/2017 (X.25.) ${ }^{38}$ provides a real novelty, as the Constitutional Court defined the principle of precaution in this decision, i.e. the Hungarian constitutional concept of

\footnotetext{
${ }^{33}$ It should be noted at this point that László Fodor has already indicated in a study published in 2007 that there are principles of environmental law that have not been used by the Constitutional Court so far, but could have been effectively invoked to interpret and enforce the right to a healthy environment. Within this circle, Fodor specifically mentions the precautionary principle. Cf.: Fodor 2007, 18.

34 During the processing of the topic, we relied heavily on the research results of Janos Ede Szilágyi. See more in this regard: Szilágyi 2018, 76-91. In connection with the practice of the precautionary principle in the Hungarian Constitutional Court see: Olajos 2019, 1391-1412.

35 The reasoning of Decision 3223/2017 [27].

${ }^{36}$ Szilágyi 2018, 79.

37 The reasoning of Decision 27/2017 [49] states the following: "According to the generally accepted precautionary principle in environmental law, the state must ensure that the deterioration of the state of the environment does not occur as a result of a particular measure."

${ }^{38}$ For the detailed analysis of the decision, see: Csák 2018, 29-32.
} 
the principle was born. ${ }^{39}$ According to the decision, "the legislator must also take into account the precautionary principle", i.e. the addressee of the principle is, in accordance with Decision 3223/2017, the legislator. The decision also states that, in accordance with the precautionary principle, "the State must demonstrate that, in the light of scientific uncertainty, the deterioration of the state of the environment as a result of a particular measure will certainly not occur". ${ }^{40}$

After such antecedents, we arrive at the judgment of the Constitutional Court on the protection of groundwater resources, Decision 13/2018. In this decision, the Constitutional Court raised the precautionary principle to a constitutional criterion, meaning that it no longer requires the simple observance of the precautionary principle but also defines a procedure in accordance with the principle as a requirement for legislation. The Constitutional Court derived all this from Paragraph (1) Article P), which reflects the idea of responsibility towards future generations, more precisely from the phrase "the obligation to preserve the common heritage of the nation for future generations." 41 With regard to the precautionary principle, another important finding of the decision is that the Constitutional Court considers the principle to be enforceable not only in connection with the prohibition of regression but also independently. With regard to the application of the precautionary principle in connection with the prohibition of regression, the Constitutional Court states as follows: "Therefore, on the basis of the precautionary principle, when a regulation or measure may affect the state of the environment, the legislator should verify that the regulation is not a step-back and this way it does not cause any irreversible damage as the case may be, and it does not even provide any ground in principle for causing such damage". The decision then sets out in which case the precautionary principle applies independently, stating "in the case of regulating cases not regulated before, the precautionary principle is enforced not only in the context of non-derogation, but also individually: with regard to those measures that do not formally implement a step-back, but they influence the condition of the environment, also the precautionary principle shall pose a restriction on the measure, and in this respect the legislator shall be constitutionally bound to weigh and to take into account in the decision-making the riskes that may occur with a great probability of for sure." 42

Since the adoption of Decision 13/2018, the precautionary principle has been included in three further decisions. Decision 4/2019 (III.7.) and Decision 14/2020 (VII.6.) confirmed the previous practice of the Constitutional Court, i.e. the constitutional significance and applicability of the precautionary principle, ${ }^{43}$ while in Decision 3/2020 (I.3.) the precautionary principle was mentioned in the context of the

\footnotetext{
39 Szilágyi 2018, 80.

40 The reasoning of Decision 28/2017 [75]; The decision also refers to domestic, European Union and international sources of law, as well as case law, according to which the precautionary principle can be considered recognized and applicable. However, the presentation of the relevant sources of law and case law is not the purpose of the present work, see in this regard: Szilágyi 2018, 80-82.

${ }^{41}$ The reasoning of Decision 13/2018 [13]-[14].

${ }^{42}$ The reasoning of Decision 13/2018 [20].

${ }^{43}$ Cf.: The reasoning of Decision 4/2019 [74], [79], [93], [99]-[100]; and also the reasoning of Decision 14/2020 [36]-[37], [128], [183].
} 
protection of human health. At this point, we, therefore, see that the Constitutional Court finds the precautionary principle applies and can be applied not only in relation to the right to a healthy environment and environmental protection but also - in this case - in the context of the right to health. It should also be noted that the Constitutional Court has previously indicated in Decision 13/2018 that, in addition to Paragraph (1) Article XXI, the principle also applies in general. ${ }^{44}$ The latter decision was therefore not based on an environmental matter, so the precautionary principle does not appear in connection with the right to a healthy environment, however, the concurring reasoning of Constitutional Judge Marcel Szabó attached to the decision contains several important findings. According to the Constitutional Jude, the precautionary principle can be interpreted in the context of the right to a healthy environment, the protection of the environment, and the protection of human health. He then - following the directions of the interpretation of the Constitutional Court summarizes the essence of the principle, stating "if there is an uncertainty about the existence or the extent of a risk threatening human health and/or the environment, the precautionary principle may justify the action of the law-maker in the form of adopting new restrictive measures." 45 According to Constitutional Judge Szabó, the Constitutional Court's practice on the precautionary principle - i.e. its interpretation as a constitutional principle is reinforced by the fact that the Minister of Human Resources and the Minister of National Development stated in their joint ministerial resolution (amicus curiae opinion) that in the event of potential risks, the legislator is obliged to act in accordance with the precautionary principle. ${ }^{46}$

At this point, it is worth briefly referring to the dissenting opinions as well as the concurring reasoning related to the decisions affected by the precautionary principle, as they show the extent to which the constitutional judges have been divided about raising the precautionary principle to the level of constitutional criterion. The main criticism of the precautionary principle can be attributed to Constitutional Judge András Zs. Varga, who mentions, among other things, that the Constitutional Court, 'fused' the precautionary principle from the text of the Fundamental Law, as it has done with the prohibition on regression. Exceeding its powers to interpret the Fundamental Law, the Constitutional Court has entered into a kind of 'co-constituent role' for which, however, it has no authority. ${ }^{47} \mathrm{~A}$ similar view is taken by Egon Dienes-Oehm, who has repeatedly drawn attention to the difficulties of applying certain principles of environmental law (such as the non-derogation principle and the precautionary principle). ${ }^{48}$ At the same time, many constitutional judges consider it forward-looking

\footnotetext{
44 The reasoning of Decision 13/2018 [14].

45 The reasoning of Decision 3/2020 [128].

46 The reasoning of Decision 3/2020 [132].

47 The reasoning of Decision 13/2018 [131] and [133].

48 The reasoning of Decision 13/2018 [109] and the reasoning of Decision 14/2020 [192]; Imre Juhász also joined the criticism of András Zs. Varga and Egon Dienes-Oehm. Cf.: the reasoning of Decision 13/2018 [114].
} 
that the Constitutional Court has incorporated the precautionary principle into its practice. ${ }^{49}$

After reviewing the case law, it can be stated that according to the interpretation of the Constitutional Court the precautionary principle plays a decisive role in the system of protection of the right to a healthy environment, in addition to the principle of non-derogation and prevention, and accordingly, the Constitutional Court consistently refers to the precautionary principle in its decisions of recent years. However, the detailed rules necessary for the practical application of the principle are not yet known, their elaboration is the task of the Constitutional Court for the future.

\subsection{The emergence of the interests of future generations in the dogmatics of the right to a healthy environment}

In addition to the development of law in connection with the precautionary principle, the provisions of the Fundamental Law declaring the protection of the interests of future generations and their interpretation have also appeared with great emphasis in the practice of the Constitutional Court in recent years. ${ }^{50}$ It should be noted at the outset that the representation and protection of the rights and interests of future generations that are without legal personality, rooted in the principle of sustainable development, ${ }^{51}$ is closely linked to the concept of the right to a healthy environment today. ${ }^{52}$

Decision 16/2015 was the first time that the Constitutional Court first dealt with the provisions of the Fundamental Law declaring the protection of the interests of future generations in substance - doing so primarily through the interpretation of Article P). The decision points out that, although Paragraph (1) Article P) of the Fundamental Law does not define exhaustively the scope of natural resources to be protected, it nevertheless states what environmental protection, as a state and civic obligation, entails. Based on this, we can speak of a triple obligation, which includes the obligation to protect, maintain, and preserve for future generations. The decision also states in connection with Article P) that the state obligation was thus independently regulated in the Fundamental Law and that the extension of the scope of obligations can be considered forward-looking, especially because only state obligations were emphasized under the previous Constitution regarding environmental protection. ${ }^{53}$

Going further in interpretation, the Constitutional Court supplemented the above in Decision 3104/2017 (V.8.) stating that "Paragraph (1) Article P) is such a pillar of the institutional protection guarantees of the fundamental right to a healthy environment, which establishes the preservation of the natural and built environment, the common, natural and cultural

\footnotetext{
${ }^{49}$ In addition to the above cited concurring reasoning of Marcel $S_{z a b o ́}$, the concurring reasoning of Ágnes Czine (paragraphs 81 to 84) and István Stumpf (paragraph 106) to Decision 18/2013 should also be mentioned.

${ }^{50}$ See more in this regard: Szilágyi 2021b, 223-233.

${ }^{51}$ Bándi 2020, 1181. and 1186.

${ }^{52}$ Cf.: Bándi 2020, 1194.; Fodor 2013, 343., Fülöp 2012, 77.

${ }^{53}$ The reasoning of Decision 16/2015 [92].
} 
heritage of the nation for future generations as a constitutional responsibility of the state and the general responsibility for everyone and declares it a duty under the Fundamental Law." 54 Although the Fundamental Law and the Constitutional Court referred to the general and joint obligation of everyone concerning the constitutional responsibility for the common heritage of the nation, at the same time the decision emphasizes the primacy of the state obligation within this responsibility, based on the fact that "the coordinated enforcement of this responsibility through institutional protection guarantees, the creation, correction, and enforcement of the institutional protection is a task of the state directly and primarily." 55

As we have seen in the decisions of the Constitutional Court analyzed so far, the protection of the interests of future generations was deduced by the Constitutional Court from Paragraph (1) Article P), which is also confirmed by Decision 28/2017. At the same time, in the context of the reasoning of the Constitutional Court, the prohibition of regression already appears in this context. In that regard, the decision states that "Article P) of the Fundamental Law implies the will of the constituent assembly to protect buman life and living conditions, particularly arable land and related biodiversity, in such a way as to ensure the life chances of future generations and not to worsen it, based on the generally accepted principle of non-derogation". ${ }^{56}$ However, Decision 28/2017 already links the protection of the interests of future generations to Article 7 of the National Avowal, ${ }^{57}$ Article 38 on the fundamental constitutional issues of public finances ${ }^{58}$ and the right to the environment $^{59}$ (including, in addition to Article XXI, which declares the right to a healthy environment, the environmental provisions of Article XX). We can see that the Constitutional Court no longer bases the constitutional protection of the interests of future generations solely on Article P). Another important finding of the analyzed decision is that "Paragraph (1) Article P) confers a bypothetical future beritage on future generations." At this point, the decision analyzes the category of "common heritage of the nation", comparing it with the categories of 'common cause of humanity' in the Convention on Biological Diversity, the 'heritage of European peoples' in the Birds Directive and the 'natural heritage' in the Habitats Directive. After the comparison, the Constitutional Court finds that the category in Paragraph (1) Article P) of the Fundamental Law can be considered as a concretization of these concepts, "according to this, the Hungarian citizens and the Hungarian state undertake that the institutional system of the state will ensure the protection of the values fixed in a non-exhaustive manner in Paragraph (1) Article P) for future generations as well. All this can be seen as a concrete commitment to the »common cause of bumanity that exists in international law."60 The Constitutional Court then defines the obligations of the present generations arising from Paragraph (1) Article P). These three obligations are: (a) to ensure choice, (b) to preserve quality, and (c) to ensure access. Paragraph [33] of the decision of the Constitutional Court defines this triple system of

54 The reasoning of Decision 3104/2017 [37].

55 The reasoning of Decision 3104/2017 [39].

56 The reasoning of Decision 28/2017 [28]; the decision confirms this at Paragraph [32].

57 The reasoning of Decision 28/2017 [25].

58 The reasoning of Decision 28/2017 [24].

59 The reasoning of Decision 28/2017 [26].

${ }^{60}$ The reasoning of Decision 28/2017 [31]. 
requirements along with the following content elements: (a) Based on the requirement of ensuring choice the living conditions for future generations can be most effectively ensured if the inherited natural heritage can provide future generations freedom of choice in solving their problems, rather than putting them on a forced trajectory. (b) Based on the requirement to preserve quality, present generations should strive to pass on the natural environment to future generations at least in such a state as they have inherited it from previous generations. (c) And based on the requirement of access to natural resources, present generations are free to have access to the resources at their disposal as long as the equitable interests of future generations are respected.

In this context, the Constitutional Court states, as a sort of conclusion, that "the legislator can only meet these fundamental expectations if it takes long-term, cross-governmental cycles into account when making its decisions." 61

Going further in the line of Constitutional Court decisions, Decision 13/2018 confirms the previous practice of the Constitutional Court regarding the protection of the interests of future generations and even goes beyond it in one point. The Constitutional Court now links the interests of future generations not only to the prohibition of regression but also to the other two fundamental principles of environmental law, the principle of prevention and the precautionary principle. In that regard, the decision states that "one of the purposes of the responsible management of the property belonging to the common heritage of the nation, as stated in the Fundamental Law, namely, the definition of the needs of future generations is not a political matter, it can and should always be determined with scientific need, taking into account the precautionary principle and the principle of prevention". ${ }^{62}$

Of the most recent environmental decisions, Decision 14/2020 is relevant to the subject under consideration. In this decision, the Constitutional Court assesses the provisions of Article P) as a constitutional formulation of the public trust doctrine, which on the one hand includes the state acting as a kind of trustee for future generations as beneficiaries and managing the natural and cultural values entrusted to it. On the other hand, it imposes a kind of restriction on present generations by "allowing the use and exploitation of these resources only to the extent that it does not jeopardize the long-term survival of natural and cultural assets as these assets are to be protected for their own sake". Another important finding for our topic of the decision is that this subparagraph of Article P), that is, the constitutional provision declaring the obligation to preserve natural and cultural values for future generations is considered by the Constitutional Court to be part of universal customary law. In conclusion, the Constitutional Court states that "the state must take into account the interests of both present and future generations when managing these treasures and creating regulations for them." 63

Not only is it positive and forward-looking that the legislator has enshrined the interests of future generations and their protection in the Fundamental Law at several points and different contexts, but also that in the practice of recent years the

${ }^{61}$ The reasoning of Decision 28/2017 [34].

62 The reasoning of Decision 13/2018 [15]; moreover, that connection is already referred to in Paragraph [13] to [14] of the decision.

63 The reasoning of Decision 14/2020 [22]. 
interpretation and the filling of these provisions with content has begun. For all these reasons, it can be stated that the Constitutional Court has laid the basic foundations of interpretation, but at the same time, as explained in connection with the precautionary principle, detailed rules are needed for the interests of future generations to prevail in practice, both in legislation and in law enforcement.

\section{Conclusions}

After reviewing the case law of the Constitutional Court of Hungary related to the subject of the study, the main conclusion is that the Constitutional Court confirmed the main elements of the dogmatics of the right to a healthy environment, and at the same time established the link between the previous and current constitutional regulations. In other words, the previous case law of the Constitutional Court regarding the right to a healthy environment is maintainable and can be applied in the future. At the same time, this means that the fourth amendment to the Fundamental Law of Hungary did not affect the dogmatics of the right to a healthy environment essentially, and its validity.

Examining the case law of the Constitutional Court in recent years, it can also be stated that new directions and tendencies can be observed in the constitutional interpretation of the right to a healthy environment, which can be traced back primarily to the new, changed constitutional regulation. The precautionary principle as a constitutional principle and the emergence of the interests of future generations in the case law of the Constitutional Court can be considered forward-looking. In these areas, the Constitutional Court has already laid the groundwork for interpretation, but the detailed rules necessary for the practical application of the precautionary principle and the effective consideration and enforcement of the interests of future generations remain to be seen. However, the elaboration of these detailed rules is also a task that awaits the Constitutional Court in the future. 


\section{Bibliography}

1. Antal A (2011) Az új Alaptörvény környezetvédelmi filozófiája, Közjogi Sẓmle 2011/4, pp. 43-51.

2. Bándi Gy (2013) A környezethez való jog értelmezése a fenntartható fejlődési stratégia és az Alaptörvény fényében, Acta Humana 2013/1, pp. 67-92.

3. Bándi Gy (2017) Környezeti értékek, valamint a visszalépés tilalmának értelmezése, Iustum Aequum Salutare XIII. 2017/2, pp. 159-181.

4. Bándi Gy (2020) Az állam elkötelezettsége a jövő nemzedékek iránt, in: Csink L, Schanda B \& Varga Zs. A (eds.): A magyar közjog alapintézményei, Pázmány Press, Budapest, pp. 1181-1201.

5. Csák Cs (2018) A földforgalmi szabályozás alkotmányossági kérdései, Agrár-és Környezetjog 13(24), pp. 5-32, doi: https://doi.org/10.21029/JAEL.2018.24.5

6. Fodor L (2006a) Környezetvédelem az. Alkotmányban, Gondolat Kiadó - Debreceni Egyetem Állam- és Jogtudományi Kar, Budapest.

7. Fodor L (2006b) A visszalépés tilalmának értelmezése a környezetvédelmi szabályozás körében, Collectio Iuridica Universitatis Debreceniensis Tomus VI, pp. 109-131.

8. Fodor L (2006c) Az Alkotmánybíróság környezetvédelmi határozatainak kritikája, Collectio Juridica Universitatis Debreceniensis Tomus V, pp. 53-99.

9. Fodor L (2007) A környezethez való jog dogmatikája napjaink kihívásai tükrében, Miskolci Jogi Szemle 2 (2007) 1, pp. 5-19.

10. Fodor L (2011) Természeti tárgyak egy új alkotmányban, Pázmány Law Working Papers 2011/21, pp. 1-9.

11. Fodor L (2013) A víz az Alaptörvény környezeti értékrendjében, Publicationes Universitatis Miskolcinensis Sectio Juridica et Politica XXXI, pp. 329-345.

12. Fodor L (2018) A precíziós genomszerkesztés mezőgazdasági alkalmazásának szabályozási alapkérdései és az elővigyázatosság elve, Pro Futuro 2018/2, pp. 42-64.

13. Fülöp S (2012) Az egészséges környezethez való jog és a jövő nemzedékek érdekeinek védelme az Alaptörvényben, in: Csák Cs (ed.): Jogtudományi tanulmányok a fenntartható természeti eröforrások témakörében, Miskolci Egyetem, Miskolc, pp. 76-87.

14. Horváth G (2013) Az Alaptörvény környezetjogi elöírásai, in: Szoboszlai-Kiss K \& Deli G (eds.): Tanulmányok a 70 éves Bihari Mihály tiszteletére, Universitas-Győr, Győr, pp. 222-234.

15. Kiss B (2017) Az ember és a környezet kapcsolata alkotmányi szabályozásának egyes kérdései, in: Balogh E (ed.): Honori et virtuti. Tanulmányok Bobvos Pál 65. születésnapjára, Iurisperitus Kiadó, Szeged, pp. 250-258.

16. Majtényi B (2010) Félreértett jogosultságok - bizonytalan belyzetü alapjogok Magyarországon, L’Harmattan Kiadó, Budapest.

17. Olajos I (2019) The precautionary principle in the practice of the Hungarian Constitutional Court and the connected agricultural innovations, Zbornik Radova 53 (2019) 4, pp. 1391-1412. 
18. Raisz A (2012) A vízhez való jog egyes aktuális kérdéseiről, in: Csák Cs (ed.): Jogtudományi tanulmányok a fenntartható természeti eröforrások témakörében, Miskolci Egyetem, Miskolc, pp. 151-159.

19. Szilágyi J E (2018) Az elővigyázatosság elve és a magyar alkotmánybírósági gyakorlat - Szellem a palackból, avagy alkotmánybírósági magas labda az alkotmányrevízióhoz, Miskolci Jogi Szemle 13 (2018) 2, pp. 76-91.

20. Szilágyi J E (2021a) A magyar zöld ombudsmanok tevékenysége a géntechnológiai szabályozás tükrében, in: Tahyné Kovács Á (ed.): Vox generationum futurorum: Ünnepi kötet Bándi Gyula 65. születésnapja alkalmából, Pázmány Press, Budapest, pp. 455-464.

21. Szilágyi J E (2021b) Észrevételek a jövő nemzedékek érdekeinek alkotmányjogi védelme kapcsán, különös tekintettel a környezethez való joghoz és környezetvédelemhez kapcsolódó más kérdéskörök vonatkozásában, in: Kruzslicz P, Sulyok M \& Szalai A (eds.): Liber Amicorum László Trócsányi: Tanulmánykötet Trócsányi László 65. születésnapja alkalmából, Szegedi Tudományegyetem Állam- és Jogtudományi Kar Nemzetközi és Regionális Tanulmányok Intézete, Szeged, pp. 223-233.

22. Szilágyi J E, Hojnyák D \& Jakab N (2021) Food Sovereignty and Food Security In Hungary: Concepts and Legal Framework, Lex et Scientia XXVIII. 2021/1, pp. $72-86$.

23. Trócsányi L (2014) Az alkotmányozás dilemmái. Alkotmányos identitás és európai integráció, HVG-ORAC Lap- és Könyvkiadó, Budapest.

24. T. Kovács J (2015) A GMO-mentes Alaptörvény hatása a mezőgazdaságra különös tekintettel a visszaszerzett EU tagállami szuverenitásra és a TTIP-re, in: Szalma J (ed.): A Magyar Tudomány Napja a Délvidéken - 2014, Vajdasági Magyar Tudományos Társaság, Újvidék, 300-319.

25. T. Kovács J (2017) Az élelembez való jog társadalmi igénye és alkotmányjogi dogmatikája, PhD thesis, Pázmány Péter Katolikus Egyetem, Budapest.

26. Varga Zs. A (2016) Történeti alkotmányunk vívmányai az Alaptörvény kógens rendelkezésében, Iustum Aequum Salutare XII. 2016/4, pp. 83-89. 